Hao, Y. \& Shao, Y. (2020). The Roles of Soundscape Approaches in Landscape Design. Landscape Architecture Frontiers, 8(1), 72-83. https.//doi.org/10.15302/J-LAF-1-020018

\section{声景方法在景观设计中的作用 \\ THE ROLES OF SOUNDSCAPE APPROACHES IN LANDSCAPE DESIGN}

蒿奕颖

英国必维国际检验集团高级工程师

邵钰涵*

同济大学建筑与城市规划学院景观学系助理教授

HAO Yiying

Senior Consultant at Bureau Veritas UK

SHAO Yuhan

Assistant Professor, Department of Landscape, College of Architecture and Urban Planning, Tong] University

*通讯作者

地址：上海市四平路 1239 号同济大学建筑与城市规划学院景观学系B129室

邮编: 200092

邮箱： shaoyuhan@tongji. edu. cn
摘要

声景源于人们对特定空间需求和期望的感 知与理解, 是一种非视觉的观察与表达形式。与 视觉景观类似, 声景的成本效益亦有相当的吸引 力。然而, 对于如何将声景方法融入景观设计, 目前设计师和相关从业者尚未有充分的理解和应 用。本文主要通过英国的相关研究成果、国家政 策及最前沿的设计实践，探讨声景方法在景观设 计中的作用。尽管相关的研究尚不充分, 但已有 研究证明, 特定景观设计要素可从声屏障及积极 声源方面对声景的营造有所助益。此外，相应政 策应鼓励城乡地区保有适宜的声景并维持其多样 性，以供景观设计师针对噪声问题提出更多创新 设计方案。景观设计方案需要通过团队协作和思 维创新来进一步探索行之有效的设计方法, 而将 交通主管部门和开发商等不同群体的利益考虑在 内的声景方法即可实现这一目标。在景观设计师 和城市规划师的协助下，协调各方利益的设计方 案可通过创造理想的城市声景予以明确。

\section{关键词}

声景方法; 景观设计; 声掩蔽; 感知; 声环境

\section{ABSTRACT}

Soundscape starts from human's perception and understanding of users' needs and expectations of a space in an un-visual observation and expression form. Similar to visual landscape, soundscape cost benefit can be rather attractive. However, how to integrate soundscape approaches into landscape design has not been sufficiently understood or applied by designers and practitioners. This paper aims to discuss the roles of soundscape approaches in landscape design by exploring the research outcomes, national policies, and the state-of-the-art design practice especially across the UK. The design elements of landscape have been demonstrated to be able to form positive soundscape in terms of both noise barrier and positive sound source, although there is still a lack of research on soundscape approaches in landscape design. Besides, relevant policies should encourage appropriate soundscapes and diversity of soundscapes in both urban and rural areas, which could provide more possibilities for landscape designers to create innovative design solutions for noise problems. The landscape design options need further development through collaboration and innovative thinking so that a greater variety of solutions can be implemented. Soundscape approaches are those which take into account interests of different groups, including transport authorities and developers. Coordinated solutions can be defined with the help of landscape and urban architects to fulfil stakeholders' interests by creating a desirable urban soundscape.

\section{KEYWORDS}

Soundscape Approach; Landscape Design; Sound Masking; Perception; Acoustic Environment

\section{基金项目}

国家自然科学基金青年科学基金项目“城市自然景观视觉舒适度感应机理研究” (编号: 51808393) 北京林业大学重点实验室开放基金项目 “乡村可持续人居环境建设研究” (编号: BJFUKF201902)

\section{RESEARCH FUNDS}

Visual Comfort Sensing Mechanism Research on the Urban Natural Landscape, National Nature Science Foundation for Young Scientists of China (No. 51808393)

Research on Rural Sustainable Habitat Construction, Key Laboratory Open Fund Project of Beijing Forestry University (No. BJFUKF201902)

编辑 王颖

EDITED BY WANG Ying 


\section{1 引言}

“声景”概念最初源于音乐和声学生态学领域。20世纪70年代, 加拿大作曲家雷蒙德 - 默里 - 谢弗将世界比作一种乐器或一首曲目, 并由此提出 “世界之律调”一说, 认为人类有义务推动实现声环境的 和谐状态 ${ }^{[1]}$ 。自21世纪以来, 有关声景的学术研究不断兴起, 声景概念 在声学、建筑学、环境健康学、心理学、社会学和城市研究等其他 学科中得到了迅速拓展。声景方法即一系列感知并构想周围声音的 方法 ${ }^{[1]}$ 。在声学领域, 研究者多关注从人类感知的视角 (如愉悦感、自 然感、烦躁感) 来评估声环境的特性。这类评估多涉及跨感官感知 ${ }^{[2]}$, 特别是听觉 - 视觉的相互作用。视听的交互可以带来更为舒适的感知 体验, 并唤醒与声环境相关的感觉。由于在听觉感知上存在声音的互 相干扰 (如声掩蔽 ${ }^{[3]}$ ), 声景研究的对象多侧重于多个声音, 而非单一 声音。以声音事件的识别与分类为核心的领域则聚焦于对全球声环境 中声音的区分。对声音的评估通常从正反两方面进行, 一方面将声音 作为设计要素, 另一方面又必须考虑噪声控制。声景制图侧重于从人 类感知因素——而非纯粹的声级——来反映声环境性质。声景生态学 还可应用于生物多样性、鸟类学和生态健康评估等研究。与声景有关 的丰硕研究成果可为景观设计与规划、噪声管理、交通设计、文化遗 产保护等提供理论依据。

空间使用者通常是声景的感知主体。在声景感知过程中, 当使 用者已悉知声景的构成、模式及变化时, 就能使自身免于 (消极) 声 景的干扰，并调整自身对声景的期望。如果声音感知这一复杂的链式 过程因故中断或受到干扰，使用者也会对此做出防范和回应。个体感 知声音的舒适度由其 (有意识与潜意识的) 感知以及生理和心理反应 中和而成。一般而言, 这些反应包括意图、关注、即时行为和前瞻行 为。正由于这种心理学上的相互依赖性, 声景方法远比传统的噪声控 制方法复杂得多。

\section{Introduction}

The concept of soundscape is originally rooted in the research fields of music and Acoustic Ecology, where in the 1970s Raymond Murray Schafer compared the world to a musical instrument or a composition and referred to the concept of "tuning of the world," suggesting that humans are responsible for the sonic environment to achieve a kind of state of harmony ${ }^{[1]}$. Academic research on soundscape has emerged since the early 21 st century, spreading quickly to other disciplines, including Acoustics, Architecture, Environmental Health, Psychology, Sociology, and Urban Studies. The soundscape approach refers to the holistic approaches to perceiving and conceiving the surrounding sound ${ }^{[1]}$. In acoustic domains, researchers are interested in evaluating acoustic environment quality from the perspective of human perception (e.g., pleasantness, naturalness, and annoyance). Cross-modal perception ${ }^{[2]}$, especially aural-visual interaction, is considered in the evaluation, which can induce more comfortable perception and associated feelings of sonic environment. Multiple sounds, rather than one sound, are studied in soundscape, considering the interruption among the sounds in terms of auditory perception (e.g., auditory masking ${ }^{[3]}$ ). Distinguishment of sounds in a global sonic environment is studied in domains of identification and taxonomy of sound events. Sounds are evaluated from both positive and negative aspects, regarding sounds as design elements along with noise control. Soundscape mapping intends to map the sonic environment quality values by weighing more factors of human perception than purely numbers of sound levels. Moreover, Soundscape Ecology is also employed in the studies on biodiversity, ornithology, and ecological well-being assessment. The fruitful research outcomes may contribute to providing theoretical guidance to more fields such as landscape design and planning, noise management, transport design, and cultural heritage protection.

Users of spaces are active perceivers in daily soundscapes. The users prevent themselves from being annoyed and adapt their expectation when they are familiar with the compositions, patterns, and changes of the soundscape. Defensiveness and conflicts may occur when an accident or interruption disturbs this complex chain of sound perception. Individual's acoustic comfort is moderated by their perception (both conscious and subconscious) as well as psychological and biological responses. In general terms these responses are managed through intention, attention, and immediate action, and pro-action. These interdependencies make soundscape approaches more complex than traditional noise control methods. 
声景方法可视为一种投资。从成本效益角度来讲, 声景与视觉景 观一样, 在吸引人流和商业活动、资产增值、健康疗愈, 以及幸福感 与生活质量提升方面具有相当的吸引力 ${ }^{[4][5]}$, 欧洲国家的一些优秀声景 设计实践也已印证了这一点 ${ }^{[6]}$ 。传统的噪声控制方法重点关注噪声声压 级是否超标以及是否符合噪声污染控制相关规范与执行标准。但积极 的声景营造和城市绿化设计却是更具可持续性和生态性的解决方案, 这类举措注重城市环境的改善, 目的在于吸引居民择居、商业活动、 劳动力和市场集聚, 而不是单纯地降低噪声声压级 ${ }^{[4]}$ 。

声景与视觉景观高度关联, 彼此互为 “语境”。新兴的声景研究 正迅速为景观设计中的声景方法贡献理论层面的创新性实证案例。声 景管理举措也得到印证, 即可通过掩蔽城市噪声来减少对生物体交流 造成的影响，从而保护生物栖息地，提高城市地区的景观品质 ${ }^{[7][8]}$ 。

\section{2 声景原则}

\section{1 声景语境}

国际标准化组织 (ISO) 新近确定的声景定义为 “特定场景中个 人或群体感知、体验及 (或) 理解的声环境” , 表明了 “语境” 在声 环境测量和评估中的重要性。“语境” 即声环境所处的物理空间, 它 “包括人、活动和场所在时空上的相互关系......并可通过听觉感受、 对听觉感受的理解及对声环境的反应来影响声景。” 99

目前对声环境的关注点大多集中在降低噪声声压级上, 而鲜少考 虑语境。但有关航空噪声的研究表明, 要想实现高品质的声环境, 仅 仅关注声压级是不够的, 且难以直击要害 ${ }^{[10][11]}$ 。视觉语境、声音偏好、 声源意义、使用者期望，以及有益声音和噪声之间的掩蔽效应都会显 著影响人们对声环境的反应。
Soundscape approaches can be considered an investment. Similar to visual landscape, soundscape can be rather attractive regarding cost-benefit, by attracting people, business, and economic activities, adding value in property, human health, and restoration, and generally and foremost well-being and quality of life $e^{[4][5]}$, which could be proved from the good soundscape design examples in Europe ${ }^{[6]}$. Traditional noise control methods concentrate on the sound pressure levels, and their conformity with regulations and implementation standards of the control of noise pollution. However, positive soundscape and urban greenery design are more sustainable and ecological solutions with a focus on the value of urban environment improvement to attract residents, business, workforce, and market forces, instead of purely reducing noise levels ${ }^{[4]}$.

Soundscape and visual landscape are highly connected and can be contexts for each other. Emergent soundscape studies are rapidly contributing innovative evidenced design practices to soundscape approaches in landscape architecture theoretically. Soundscape management has been also demonstrated to improve the landscape quality in urbanized areas by reducing the masking effects of urban noise on organism communication, and furthermore, encouraging the urban organism habitats ${ }^{[7][8]}$.

\section{Soundscape Principles}

\subsection{Soundscape Contexts}

The recently agreed International Organization for Standardization (ISO) definition of soundscape - " [the] acoustic environment as perceived or experienced and / or understood by a person or people, in context" - identifies the importance of context in the measurement and evaluation of the acoustic environment. Context is the physical place where the acoustic environment exists, and it "includes the interrelationships between person and activity and place, in space and time... and may influence soundscape through 1) the auditory sensation, 2 ) the interpretation of auditory sensation, and 3) the responses to the acoustic environment." ${ }^{[9]}$

Currently, most of concerns on sonic environment focus on noise level reduction without considering context. However, increasing research evidences show that the sound levels are not sufficient or straightforward for a high quality acoustic environment, strongly evidenced by the research on aviation noise ${ }^{[10][11]}$. Visual context, sound preference, meaning of sound sources, user expectation, and masking effects between unwanted and wanted sounds significantly influence human responses to sonic environment. 
Fountains in the Shea Square in Sheffield,

UK. The water feature of the steel barrier acts as both noise barrier and water sound generator for masking. Significantly different soundscapes can be observed on the two sides of the steel barrier.

\section{2 促进实现积极声音与有效声掩蔽}

声景方法将声音视为一种环境资源。以积极的态度探讨声音至关 重要, 这为利用不同的声源来改善声环境创造了更多的机会。

声掩蔽是日常生活中最重要的听觉现象之一，对声景的品质影响 重大 ${ }^{[12]}$ 。掩蔽是指由于另一种或多种声音的介人而使一种或多种声音不 可闻或部分不可闻，这是心理声学领域常被探讨的概念。掩蔽效应不 能直接降低所感知声音的响度, 但可以显著减少交通噪声的干扰, 使 声景更加自然、宜人 ${ }^{[13]}$ 。在声景设计中, 通过有益声音来掩蔽噪声的设 计手段已得到广泛认可 ${ }^{[14] \sim[16]}$ 。而通过叠加其他更有趣的声音来增强特 定的自然/人为声音或掩盖不受欢迎的声音也是可行方案之一（图1）。

\section{3 声景与视觉景观}

声景与视觉景观在空间上高度关联。户外空间中存在作为声源的多 样景观要素, 而空间声音的生命力也主要由视觉景观的属性所决定 ${ }^{[17]}$

在不同的空间场景中，人们有不同的声音偏好。一般来说，自然 声是最受青睐的声音之一 ${ }^{[18]}$ 。而在自然声中，常应用于景观设计实践中 的水声和树叶响声又最为人们所喜爱 ${ }^{[19]}$ 。与此同时, 声景作为语境与视

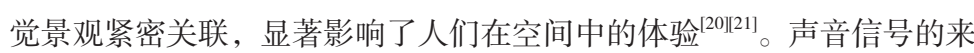

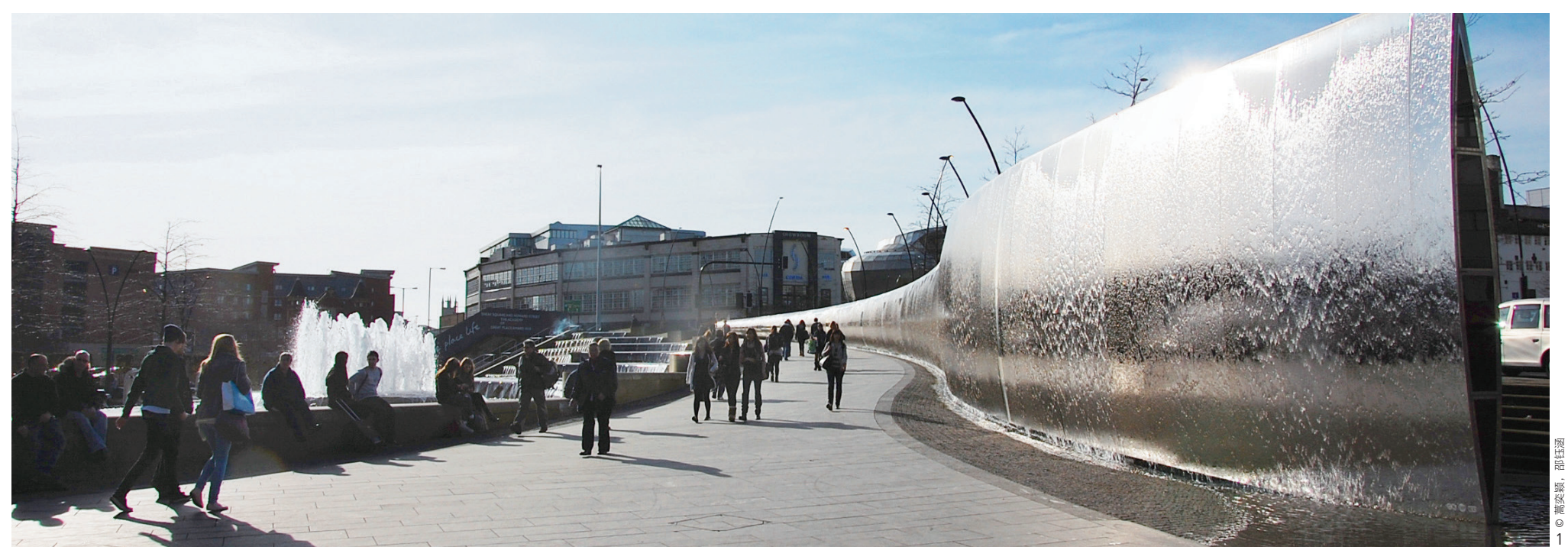

\subsection{Promoting Positive Sounds and Effective Sound Masking}

Soundscape approaches recognize sound as an environmental resource. It is essential to consider sounds in a positive way, which creates more opportunities in improving the acoustic environment with multiple sound sources.

Sound masking, one of the most significant daily-life hearing phenomena, has been proved to have considerable effects on the quality of soundscape ${ }^{[12]}$. Masking means inaudibility or partial inaudibility of (a) sound(s) due to the interruption of another sound(s), which is frequently explained and explored in Psychoacoustics. Although masking effects may not reduce perceived loudness directly, it can significantly reduce annoyance of road traffic noise and improve the naturalness and pleasantness of soundscape ${ }^{[13]}$. Masking unwanted sounds by wanted sounds is widely accepted as a design technique in soundscape design ${ }^{[14] \sim 16]}$. It is also feasible to enhance specific natural or artificial sounds, or mask undesirable sounds by superimposing other more interesting sounds (Fig. 1).

\subsection{Soundscape and Visual Landscape}

Spatially, soundscape and visual landscape are highly connected. Diverse landscape elements as sound sources exist in outdoor spaces, and the spatial sound viability is mainly shaped by visual landscape attributes ${ }^{[17]}$.

People have different sound preferences in different spatial scenarios. In general, natural sounds are ranked on top in sound preferences ${ }^{[18]}$. The natural sounds from water and foliage, commonly-used in landscape design, are believed more 
源和强度可反映视觉景观的构成和空间结构。声音的特性可以体现景 观系统的复杂性, 这些特性的形成也同时反映了景观的可变性和多样 性 ${ }^{[17120]}$ 。从时间角度来看, 声音反映了人类活动、生物过程和自然现象 的日常循环，各种声音化作景观的 “信使”，传递出不同的信息。

声景也有助于描述和分析 “基于观察者视角的景观” ${ }^{[17]}$ 。从生物 学角度来看, 听觉和视觉信号都有助于生物个体 (包括人类) 感受、 认知和利用物理空间。

城乡绿地中有多种作为非生物自然声声源的景观要素——方 面, 绿地中的植被为产生声音 (生物声) 的生物体提供了栖息地; 另 一方面，植被既可吸收声音，也可充当声源（如风吹树叶）。

视觉景观也通过听觉 - 视觉交互来影响声景。声音与其他物理条 件之间的相互作用在声景评估中极其重要, 而其中听觉 - 视觉的相互 desirable ${ }^{[19]}$. Meanwhile, soundscape is highly connected with visual landscape as context, significantly influencing the human experience in spaces ${ }^{[20][21]}$. The origin and intensity of the acoustic signals can reflect the structure and spatial configuration of the visual landscape. Sound attributes can characterize landscapes as complex systems, showing both variability and diversity of landscape in their sources ${ }^{[17][20]}$. From the temporal perspective, sound is a reflection of the daily cycle of anthropogenic activities, biological process, and natural phenomena, which produces sounds as "messengers" of the landscape.

Soundscape also contributes to the description and analysis of the "observer-based landscapes" ${ }^{[17]}$. From a biological point of view, both acoustical and visual cues can assist individual organisms (including humans) to sense, perceive, and utilize physical spaces.

Diverse landscape elements as geophony sources exist in urban and rural green spaces. Vegetation in green spaces provides habitats for sound-producing organisms (biophony) and acts as both sound absorbers and sound sources (e.g., wind goes through leaves).

Visual landscape also influences soundscape by aural-visual interaction. The interactions between acoustic and other physical conditions are very important in soundscape assessment, among which aural-visual interaction is intensively studied ${ }^{[21]}$.
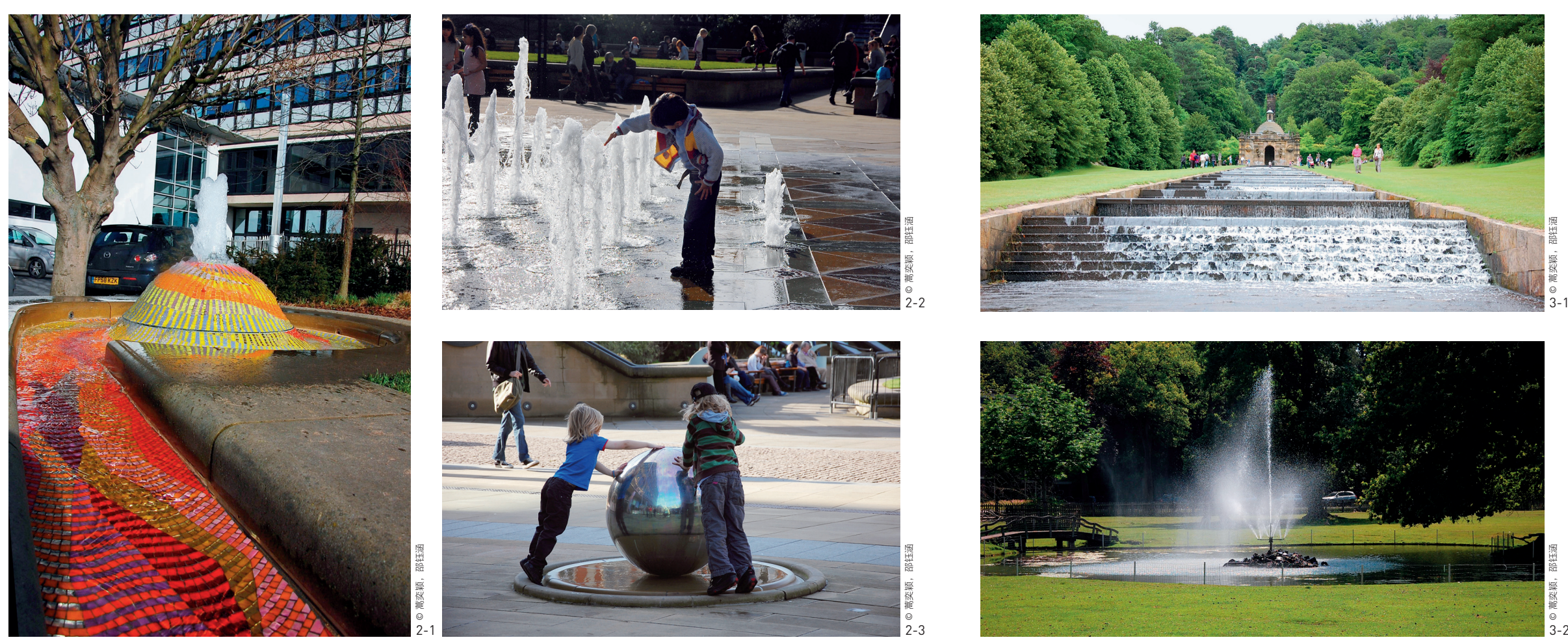

在心理上掩蔽城市噪声: 癿菲尔德市霍华德街和哈 勒姆花园（图2-1）; 伦 敦市伊丽莎白女王奥林 匹克公园中的喷泉（图 $2-2)$; 谢菲尔德市干年 广场中暂时静止的喷泉 (图2-3)。

绿地中的水景: 英国查茨 斯度目 阿桀市 (图3-2) 水 阿林市 (图3-2)。水 是观中重要的设计要 素, 可通过产生多种水声 来掩蔽人工声音, 从而促 进自然环境恢复。 areas, generating water areas, gener sounds as urban noise sound-maskers and diverting space users attention by either visual aural or tactile stimuli as urban noise mindmasker: Howard Street and Hallam Garden in Sheffield (Fig 2-1): The Sheffield (Fig. 2-1); The fountain in the Queen in in London (Fig. 2-2) Silent fountain in the Millennium Square of Sheffield (Fig. 2-3).

Water features in green spaces: Chatsworth House in the UK Fig. 3-11: Assen in (Fig. 3-1); Assen in Netherlands (Fig. 3-2) The water features are important design elements in landscap design, which could produce diverse water sounds and contribute to tranquility of restorative tranquility of restorative (1) sounds.
作用更是研究的重点 ${ }^{[21]}$ 。已有的感知实验证明，自然景色可以使声 景更为自然与宜人, 同时减少人们的烦躁感 ${ }^{[22]}$ 。这一效果象可以视 为通过注意力转移进行的掩蔽, 其中视觉景观充当了这一掩蔽的语 境（图2,3）。

\section{3 景观设计中的声景方法}

\section{1 英国规划设计政策中的声景方法}

长期以来，欧盟及英国的各类规划设计相关政策和导则都侧重 于消减环境声音的消极作用, 主要包括降低噪声并缓解其不利影响。 2012年, 欧盟议会发布了关于环境噪声评估和管理的第2002/49/EC号法 令, 即《环境噪声指令》（END）。这一指令强调了预防和减少环境噪 声的必要性, 以避免噪声对人类健康造成负面影响, 同时对良好的声 环境和安静区域进行保护。END还特别要求成员国制定噪声改善计划, 且计划中应包括主管部门为保护安静区域预备采取的行动。

2000年，《乡村白皮书》首次在英国的政策层面提及 “宁静” (tranquility) 这一表述, 认为噪声和光污染对宁静有害, 但宁静并 非意味着没有声音（例如，某些声音代表了乡村的生活方式）。2006 年, 英格兰《环境噪声条例》规定, 政府有责任确定并致力于保护英 国大型城市（或称 “城市群” ) 的安静区域, 以防随着交通量和工业 噪声的不断增加, 人们可感知的宁静逐渐减少。2010年, 《英格兰噪 声政策声明》阐述了噪声管理和控制的长期目标, 其目的是避免噪声 带来的一一尤其是健康和生活质量方面的一一重大不利影响。随后, 于2012年3月发布的《国家规划政策框架》（NPPF）明确了英格兰在 规划决策中对噪声的实质性考量。除了减少甚至避免噪声对大众健 康和生活质量的不利影响外, 确定和保护安静区域也是NPPF的首要 目标之一

威尔士政府通过在城乡地区设立试点来评价声环境中的积极声 音。政府在2015年发布的《自然资源政策声明》第5.3章节“韧性城市 社区” 中称, “鸟鸣、流水声和微风中树叶沙沙作响” 等积极声音与 绿色基础设施的健康效益有关，且 “与安全感、健康以及多感官的宁
By means of perceptual experiments, the natural view has been demonstrated to increase the naturalness and pleasantness of soundscape, and to decrease annoyance in human perception ${ }^{[22]}$. This effect can be considered as masking by attention diversion, where landscape serves as the context of the masking (Fig. 2, 3).

\section{Soundscape Approaches in Landscape Design}

3.1 Soundscape Approaches in UK's Planning and Design Policies

For a long time, relevant planning and design policies and guidance across the EU and the UK focus on eliminating the negative aspects of environmental sounds primarily through noise reduction and mitigation. In 2012, European Parliament published Directive 2002/49/EC relating to the assessment and management of environmental noise, known as Environmental Noise Directive (END). It emphasized the needs for environmental noise prevention and reduction to avoid negative impact on human health, as well as preservation of good sound environment and quiet areas. END also specifically required the member states to prepare Noise Action Plans, which should include actions of the competent authorities to preserve quiet areas.

The first mention to tranquility in the UK policy was in the Rural White Paper in 2000, where noise and light pollution were believed harmful for tranquility, but tranquility was not about absence of noise (e.g., some noises are representative of activities in rural way of life). The Environmental Noise (England) Regulations 2006 placed a responsibility on the government to identify and protect quiet areas in the UK's largest cities (referred to as "agglomerations") from increasing transport and industrial noise, which may result in decreasing perceived sense of tranquility. In 2010, the Noise Policy Statement for England stated long-term vision for noise management and control, to avoid significant adverse impacts, especially mitigating and minimizing adverse impacts on health and quality of life. Accordingly, in March 2012, the National Planning Policy Framework (NPPF) was published, clarifying the material consideration of noise in planning decisions in England. Besides avoidance and reduction of adverse noise impact on health and quality of life, identification and protection of tranquil areas were firstly included as one of the aims in NPPF.

The Welsh Government set up pilots in rural and urban areas to value positive sounds in soundscapes. In Natural Resources Policy Statement released by the government in 2015, it is claimed that positive sounds, "such as birdsong, flowing water and leaves rustling in the breeze," are related to the health benefits by green infrastructure and "associated 
静概念相联系”。 ${ }^{[23]}$ 《威尔士规划政策 ( 2016 )》指出, 要保护城市 “安静区域” 免受不断增加的噪音的影响, 但未提及“宁静” 概念。 不过，威尔士政府以 “宁静” 为主题的网站和威尔士自然资源部发布 的《自然资源状况报告 (2016) 》提出了一个较为全面的 “宁静” 的 定义: “( 宁静) 是一种平静的状态, 它平和、安静, 且未受到不必 要的干扰。其既可描述精神状态, 也可描述特定环境。宁静感可以通 过有无干扰来衡量, 也可以通过积极和消极因素的平衡来衡量。这些 因素包括自然的呈现、安全感、愉悦的视觉环境和轻松的氛围。” ${ }^{[24]}$ 该 定义既涉及环境层面, 也结合了人的精神层面, 并提及了对人为干扰 的规避（而非完全杜绝）。

根据2015年《后代福祉法》（威尔士）, 威尔士政府于 2018 年12 月颁布了《噪声与声景行动计划 (2018-2023)》和《威尔士规划政 策》 (第10版) , 首次将声景原则纳人英国规划政策。声景原则为健 全的环境管理、人类健康与福祉、减少环境不公平现象、自然/野生 区域保护等方面带来了更加可持续的发展理念。而声景实践也对实现 2015年《后代福祉法》中规定的福祉目标具有重要意义。

《噪声与声景行动计划 (2018-2023)》取代了威尔士原有的噪声 行动计划, 成为威尔士政府现行的针对噪声的核心政策文件。它概述 了威尔士公共部门在噪声和声景管理方面的战略政策方向。这一行动 计划展现了对声景和声景原则概念的充分理解, 在未来5年中, 该政策 将视声景为规划决策中的强制性考虑因素。

虽然声景概念尚未在英国的政策层面和实际监管中深人人心, 但 仍可作为有效的噪声缓解措施来施行。英格兰政府在《英格兰噪声政 策声明》 (NPSE) ${ }^{[25]}$ 中指出了其噪声政策的三项主要目标：1）避免对 健康和生活质量造成重大不利影响；2）尽量减少对健康和生活质量的 不利影响; 3 ) 在可能的情况下, 为改善健康和生活质量作出贡献。

一般进行环境噪声评估是为了证明其作为传统的噪声缓解措施可 实现NPSE的前两个目标, 但对于第三个目标的验证一尤其是对于 那些产生噪声或遭受显著噪声影响的发展领域来说一还存在一些问 with a sense of safety and well-being, and the multi-sensory concept of tranquility" in the section of 5.3 Resilient Urban Communities $^{[23]}$. Planning Policy Wales (2016) stated the need to protect urban "quiet areas" against an increase in noise, but nothing was mentioned about tranquility. However, a comprehensive definition of tranquility is given in the Welsh Government website of Tranquility and in the State of Natural Resources Report (2016) by Natural Resources Wales as "an untroubled state, which is peaceful, calm and free from unwanted disturbances. This can refer to a state of mind or a particular environment. Tranquility can be measured in terms of the absence of unwanted intrusions, or by a balancing of positive and negative factors. These include the presence of nature, feeling safe, visually pleasing surroundings and a relaxing atmosphere." ${ }^{[24]}$ This definition combines both the engagement with the environment, the state of one's mind, and the avoidance (instead of absence) of human intrusions.

Under the Well-being of Future Generations (WFG) (Wales) Act 2015, the Welsh Government published Noise and Soundscape Action Plan 2018-2023 and the Planning Policy Wales (Edition 10) in December 2018, which firstly included the soundscape principles in the UK planning policy. The soundscape principles bring in more sustainable development ideas in sound environment management, human health and well-being, environmental inequality reduction, natural / wildlife area conservation, and so on. Soundscape practice can definitely benefit the achievement of the well-being goals specified in the WFG (Wales) Act 2015.

The Noise and Soundscape Action Plan 2018-2023 replaced the old noise action plan for Wales. As the Welsh Government's recent central noise policy document, it outlines the Welsh public sector's strategic policy direction in relation to noise and soundscape management. This action plan demonstrates a good understanding of the concept of soundscape and soundscape principles, and over the next five years the policy will make soundscape a compulsory consideration.

While not yet ingrained in the UK policy and regulation, soundscape could be used as an effective noise mitigation measure. The three key objectives of the English Government's noise control strategies are set up in the Noise Policy Statement for England (NPSE) ${ }^{[25]}$ as follows: 1) avoid significant adverse impacts on health and quality of life; 2) mitigate and minimize adverse impacts on health and quality of life; and 3) where possible, contribute to the improvement of health and quality of life.

Typically the environmental noise assessment will go as 
题。声景方法在环境改善方面具有潜力, 且可能成为实现第三个目标 的有力工具。

在新居住区开发方面, 英国《国家规划实践导则》(NPPG) 建

议, 若居民能享有下列某项或多项权益, 则其所受噪声影响可在一定 程度上得到弥补：“1）住宅拥有相对安静的立面（房间有窗）；2） 拥有可供单独使用的相对安静的外部设施空间（如阳台或花园）。虽 然人们通常期望住房带有花园或阳台, 但其预期效益会随噪声暴露量 的增加而减少, 且可能产生严重的不利影响; 3 ) 拥有可供部分居民单 独使用的相对安静的、受保护的邻近外部设施空间, 作为住宅的一部 分；4) 拥有相对安静的、受保护的邻近（步行5分钟以内）公共设施 空间（如公园或其他宁静的绿地）。”[26]

在此背景下, 通过精心的建筑设计和城市设计以及将声景原理应 用于公共设施空间中, 可以很大程度地抵消噪音效应, 由此消减部分 受噪声影响的场地的规划限制。

健康的声环境并不仅仅意味着没有噪声。从概念上讲, 声景包括 某一特定环境中有益的、中性的声音以及噪声。我们需要创造更适宜 的声景, 即在合适的时间和地点创造合适的声环境, 这远比降低噪声 分贝值更具意义。城镇应纳人与各种土地利用类型相适应的声景。

\section{2 有关声景方法的研究}

在声音与其他物理条件的相互作用中, 听觉与视觉刺激间的交互 最为重要 ${ }^{[19]}$ 。根据迈克尔 - 索斯沃思的研究, 当听觉环境与视觉环境相 结合时, 视觉形式会削弱人们对声音的有意感知 ${ }^{[27]}$ 。由于人类感知中的 视听交互作用在声环境评估上具有重要影响, 近来出现了许多基于声

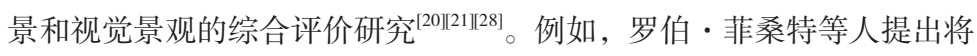

far as demonstrating that traditional mitigation measures employed in a development deliver the first and second objectives of the NPSE. The third objective of the NPSE can be more problematic to demonstrate, particularly for developments which generate, or are subject to, high levels of noise. Soundscape methods have the potential to demonstrate improvement to an environment and could be a powerful tool for schemes wishing to achieve the third objective.

In the context of new residential development, the National Planning Practice Guidance (NPPG) advises that noise effects may be partially offset if the residents of affected dwellings have access to the following conditions: “1) a relatively quiet facade (containing windows to habitable rooms) as part of their dwelling; and / or 2) a relatively quiet external amenity space for their sole use, (e.g., a garden or balcony). Although the existence of a garden or balcony is generally desirable, the intended benefits will be reduced with increasing noise exposure and could be such that significant adverse effects occur; and /or 3) a relatively quiet, protected, and nearby external amenity space for sole use by a limited group of residents as part of the amenity of their dwelling; and / or 4) a relatively quiet, protected, and external publicly accessible amenity space (e.g., a public park or a local green space designated because of its tranquility) that is nearby (e.g., within a 5 minutes walking distance)."[26]

In this context, the noise effects can be offset through careful architectural and urban design and the application of soundscape principles to external amenity spaces. This could remove planning restrictions on sites, as it would normally be refused to plan in noise grounds.

It is believed that a healthy acoustic environment is more than simply the absence of unwanted sound. Conceptually, soundscape includes beneficial and neutral sounds as well as noise in a given context. It has a broader focus than just clamping down on the decibels, recognizing that we also need to create appropriate soundscapes - the right acoustic environment in the right time and place. Towns and cities should contain a variety of soundscapes appropriate to the land use.

\subsection{Soundscape Approaches in Research}

The interplay between aural and visual stimulus is the most important among the interactions between acoustics and other conditions $^{[19]}$. According to Michael Southworth's research, when aural and visual settings were joined, the conscious perception of sound could be reduced by the visual form ${ }^{[27]}$. Because of the crucial role of visual-aural interaction of human 
自然特征作为变量通过线性表达式来评估一个地方可感知的宁静度 ${ }^{[28]}$ 。

另有新证据表明，除了噪声控制外，通过控制城市物理结构也可 以减少噪声 (例如飞行噪声) ${ }^{[29]}$ 。良好的开放空间视觉设计和景观格局 设计, 亦有可能通过声掩蔽效应减少噪声的干扰 ${ }^{[27][30]}$ 。

蒿奕颖等人在声景范畴内对自然景观和自然声音对交通噪声的掩 蔽效应进行了感知听力实验 ${ }^{[22]}$ 。研究结果表明, 自然景观显著地增加 了声环境的舒适度（图4），且自然声音通过掩蔽显著改善了交通噪音 影响下的环境质量（图5），这与以往研究结果相一致 ${ }^{[31] \sim[3]}$ 。另外, 宽 频水声可通过能量掩蔽缓解城市交通噪声，使噪声不可闻或部分不可 闻。水声亦在丰富声景方面具有显著效果，因此可以称其为 “声景的 首要品质” ${ }^{[19]}$ 。

\section{3 声景方法在实践中的应用}

近几年, 人们对声景技术的认识不断提高, 其在降低噪音、减少 对健康的不良影响，以及改善福祉和创造更理想的空间等方面的作用 也不断得到印证, 因此, 英国多家咨询公司已开始提供与声景相关的 服务。

声学顾问开始通过参与或开展声景研究和实践项目来推广声景。 他们一直积极从事声景技术的研究和实践, 包括声景及其视觉设计、 听觉感知实验、声音艺术和声景装置。声景亦因持续的大型基础设施 开发而备受关注，其中噪声评估在城市规划/设计中必不可少。

理想情况下，声景设计应始于通过问卷调查和访谈确定使用者对 户外声环境的感知, 然后进行声音测量和分析, 再绘制声景地图。最 后的设计和优化阶段则聚焦于综合措施的实施, 包括噪声控制、掩蔽设

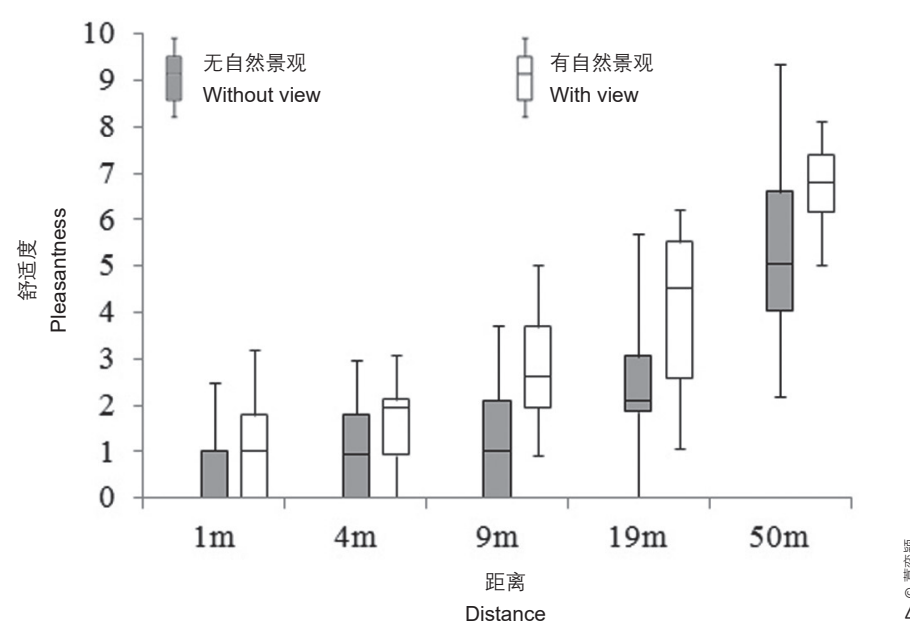

perception on sound environment assessments, integrated studies of soundscape and visual landscape have also been conducted recently ${ }^{[20][21][28]}$. For example, Rob Pheasant et al. proposed to evaluate perceived tranquility of a location by linear expressions with presented view of natural features as a variable $^{[28]}$.

There is also an emerging evidence that, besides strategies of noise control, noise (e.g., aviation noise) attenuation can also be realized by controlling urban fabrics ${ }^{[29]}$. Good visual design of open spaces and design of landscape patterns have the potential to reduce noise annoyance by sound-masking effects $^{[27][30]}$.

Hao Yiying et al. carried out perceptual listening tests on masking effects of natural view and natural sounds on traffic noise within the scope of soundscape ${ }^{[22]}$. The study demonstrated how significantly the natural view increases the pleasantness of the acoustic environment (Fig. 4) and how significantly the natural sounds can improve the environmental quality of traffic noise by sound-masking (Fig. 5) corroborating the findings from previous studies ${ }^{[31] \sim[33]}$. The wideband water sounds showed big potential in energetic masking of urban traffic noise, inducing inaudibility or partial inaudibility of noise. Water sounds have rich effects in coloring the soundscape and could be defined as a "primary soundscape quality" ${ }^{[19]}$.

\subsection{Soundscape Approaches in Practice}

Over the past few years with the increased awareness of soundscape as a technique for mitigating noise, reducing
4. 距离道路 $1 \mathrm{~m} 、 4 \mathrm{~m}$ 、 $9 \mathrm{~m} 、 19 \mathrm{~m}$ 和 $50 \mathrm{~m}$ 处, 有 自然景观和无自然景观

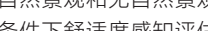

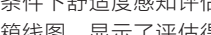
箱线图, 显示了评估得 分的统计分布 ( 来源 参考文献[33] )。

5. 距离道路 $1 \mathrm{~m}, 4 \mathrm{~m}$ 、 $9 \mathrm{~m} 、 19 \mathrm{~m}$ 和 $50 \mathrm{~m}$ 处, 在 噪声定值为 $52.5 \mathrm{~dB}(\mathrm{~A})$ 的 有鸟鸣和无鸟鸣条件下 的自然感感知评估箱线 的目然感感知评估箱线 图, 显示了评估得分的 统计分布 ( 来源: 参考 文献[33]）。

4. Box-and-Whisker Plots of the perceptual evaluations of pleasantness of the road traffic noise environments at distances of 1, 4, 9, 19 and 50 meters from the road, without view and with view, showing the statistical distribution of the evaluation scores (source: Ref. [33]).

5. Box-and-Whisker Plots of the perceptual evaluations of naturalness of the road traffic noise environments at distances of 1, 4, 9, 19 and 50 meters from the road, without birdsong and with birdsong at $52.5 \mathrm{~dB}(\mathrm{~A})$; showing the $52.5 \mathrm{~dB}(\mathrm{~A})$; showing the
statistical distribution of the evaluation scores (source: Ref. [33].

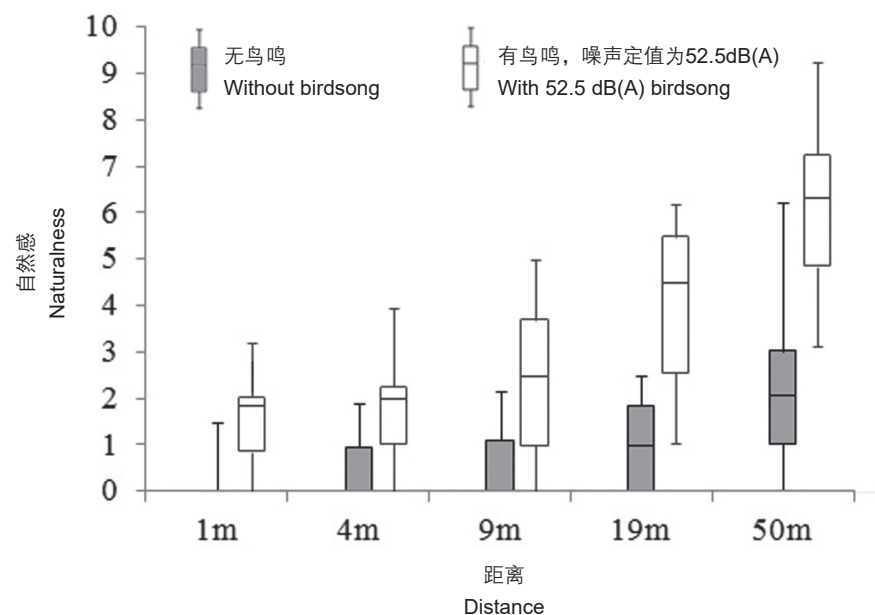

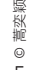



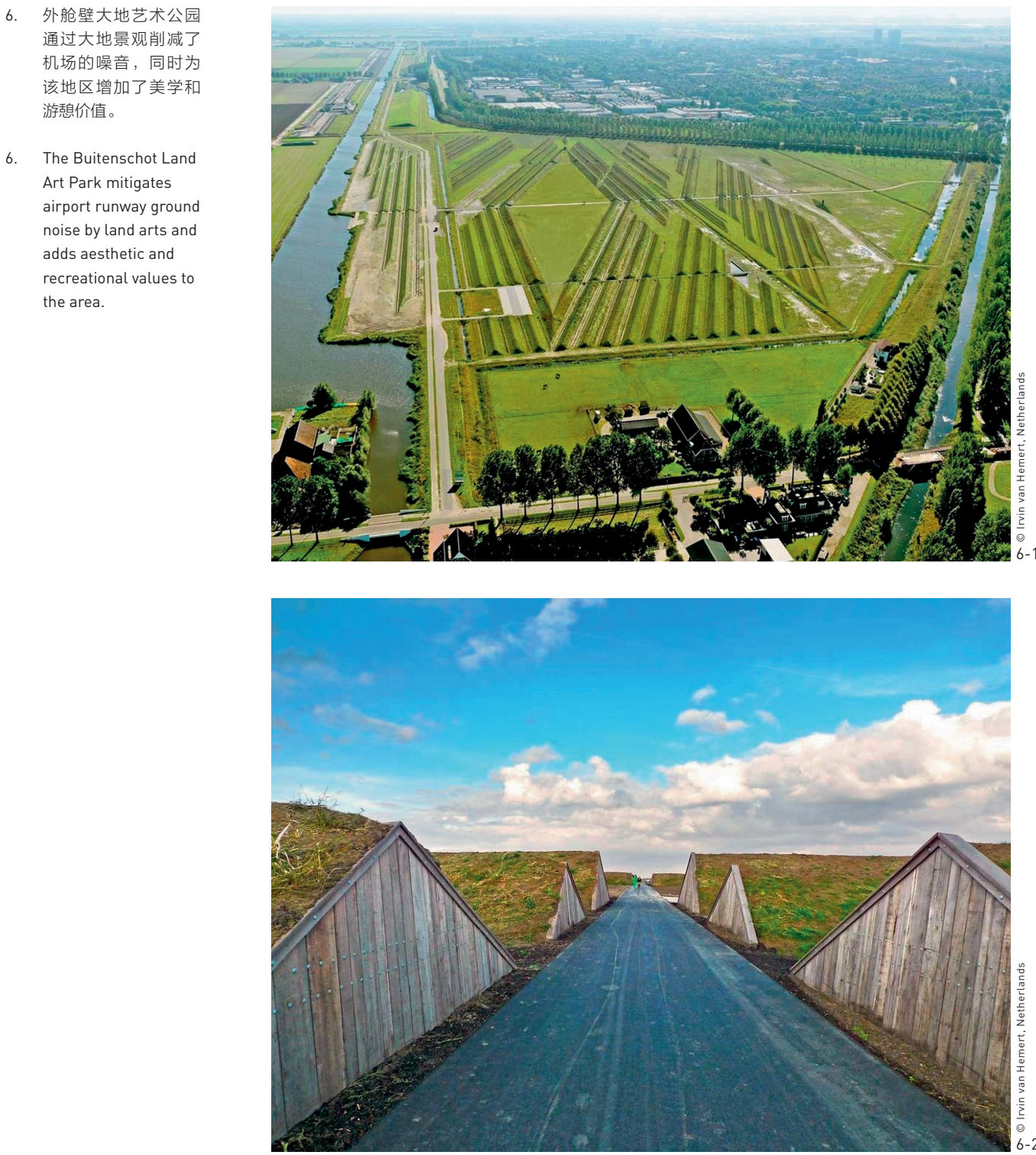

计和社会反馈调查。然而，鉴于项目时间和预算通常都十分有限，声景 设计可适当参考以往的研究成果和优秀实践案例, 无需照搬整个流程。

目前, 声景管理/设计的主要原则是增强有益声音和削弱噪声。掩 蔽策略是实现这一目标的最有力工具。心理声学掩蔽（能量掩蔽）和心 理掩蔽 (信息掩蔽) 都可用于提高声景品质。在声景设计中, 需要仔细 论证和评估掩蔽效应, 以避免使现有声景恶化。如果声景实践能受到更 广泛的关注，专业人士就能更熟悉声景原理和方法，从而将声景应用于 更广泛的景观项目中。

视觉景观设计也可以减轻噪声, 且相较于传统的噪声控制策略更 具可持续性和成本效益, 对于深受噪声干扰的区域, 效果尤为明显。 位于阿姆斯特丹史基浦机场西南侧的外舱壁大地艺术公园即为通过大 尺度景观缓解噪声的优秀案例（图6）。其景观设计结合了大地景观与 adverse health impacts, improving well-being, and creating more desirable assets, several consultancies in the UK have started to offer relevant services.

The acoustic consultants have started promoting soundscape by joining or undertaking soundscape research and practical projects. They have been active in undertaking research and practice in soundscape techniques, e.g., soundscape and visual design, subjective listening in lab, sound art, and soundscape installations. Soundscape also attracts a lot of attention from the on-going big infrastructure development, of which noise assessment is essential in urban planning / design.

Ideally, soundscape design begins with the determination of users' perception of the outdoor sound environment via questionnaire survey and interview, followed by sound measurement and analysis, and soundscape mapping. The final stage of design and optimization focuses on integrated practical measures, including noise control, design with masking, and social survey. However, given often limited project time and budget, previous research outcomes and good practice can be properly considered and referred to soundscape design in order to avoid undertaking the whole procedure.

Currently, the main principle of soundscape management / design is enhancing wanted sounds and reducing unwanted sounds. Masking is considered the most powerful tool to achieve this goal. Two means of masking, i.e., psychoacoustic / energetic masking and mind / informational masking, can both be employed in the enhancement of soundscape quality. Careful demonstration and assessment of the masking effects are needed in soundscape design to avoid worsening the existing soundscape. Once more attention is paid to soundscape practice, professionals will be more familiar with the soundscape principles and approaches, which can be applied in a wider range of projects of landscape.

Noise mitigation can also be achieved by visual landscape design, which is more sustainable and costeffective than traditional noise control strategies, particularly for the areas intrusive to noise. Buitenschot Land Art Park to the southwest of Amsterdam's Schiphol Airport is a good example of noise mitigation by largescale landscaping (Fig. 6). The landscape design integrates land arts with soundscape design to achieve the airport runway ground noise reduction sustainably by sound wave reflection. It not only reduces noise from the aircrafts but also adds aesthetic and recreational values to the area. 
声景, 通过声波反射为机场跑道地面降噪, 不仅减少了飞机带来的噪

音, 且为该地区增加了美学和游嚊价值。视觉景观与声景设计之间的 创新融合在全球环境改善和可持续发展一一特别是大型基础设施开发 方面一一具有广阔的前景。

\section{4 讨论与结论}

声景方法根植于人类的听觉感知, 深受作为其语境的视觉景观环 境的影响。声景品质的改善亦有利于视觉景观的提升, 进而提升整体 的环境设计。

尽管还需对景观中的声景方法进行更为深人的研究, 以进一步明 确视觉景观设计与声景品质的关系, 但已有研究表明, 视觉景观要素 可以通过带人积极的声音和自然景观助益声景。景观设计师可以在设 计前期对方案进行优化, 以避免噪声问题或改善噪声空间。例如, 通 过打造高频鸣声鸟类栖息地诱导鸟鸣, 利用信息掩蔽将人的注意力转 移到其他更悦耳的声音上; 水声是城市噪声的有力遮蔽器, 与城市交 通噪声声谱类似的宽频水声可以营造更加自然的气氛。设计师应精心 设计水景, 考虑掩蔽中的信噪比等因素, 使掩蔽效应更为积极有益。 视听的交互可以诱发更为舒适的感知及其他相关感觉, 因此水景的视 觉设计也有助于城市声景品质的提高。

目前已受到广泛关注的英国规划设计政策中的声景方法, 以促进 福祉和改善生活质量为目标, 而非只为降低噪声分贝值。这些政策要 求城乡地区营造适宜的声景, 同时维持声景的多样性, 设计师也可由 此拓展更多针对噪声问题的创新性解决方案。

越来越多的优秀实践表明, 景观设计方案需要通过团队协作和思 维创新来进一步探索行之有效的设计方法, 而声景方法即将交通主管 部门和开发商等不同群体的利益考虑在内。在景观设计师和城市规划 师的协助下，协调各方利益的设计方案可通过创造理想的城市声景予 以明确。LAF
It is believed that the innovative collaboration between the visual landscape and soundscape design is promising for global environmental improvement and sustainable development, especially for large infrastructure projects.

\section{Discussion and Conclusions}

The soundscape approaches are rooted in the human auditory perception, which is influenced by visual landscape settings as an important context. Meanwhile, the soundscape quality improvement can benefit the visual landscape design, and further the holistic environmental design.

It has been demonstrated that the visual landscape elements can benefit soundscape through both positive sounds and natural view settings, although more research on soundscape approaches in landscape are needed to provide evidence on the relationship between visual landscape design and soundscape quality. Landscape architects can optimize the design at the early stage to avoid or elminate noise problems. For example, the creation of habitats for birds to induce birdsong, which is mainly composed by high frequency components, will divert the attention of listeners to other more pleasant sounds in terms of informational masking. Water sounds are powerful masker for urban noise. A more natural atmosphere can be created through water sounds with similar spectrum of urban traffic noise, which is wide-band in frequency, while designers should carefully design the waterscape to include consideration of the signal-noise-ratio in masking, to make the masking more positive. Considering that the aural-visual interaction can induce more comfortable perception and associated feelings, the visual design of waterscape can also contribute to the quality of urban soundscape.

With more and more attention, soundscape approaches in UK's planning and design policies aim at the improvement of well-being and quality of life, which is beyond just clamping down on the decibels. The policies ask for appropriate and diverse soundscapes in both urban and rural areas, which provides more possibilities for designers to create innovative design solutions for noise problems.

An increasing number of good practice shows that the design options need further development through collaboration and innovative thinking for a greater variety of solutions. Soundscape approaches take into account interests of different groups, including transport authorities and developers. Coordinated solutions can be defined with the help of landscape architects and urban planners to fulfil stakeholders' interests by creating a desirable urban soundscape. LAF 
[1] Schafer, R. M. (1977). The Soundscape: Our Sonic Environment and the Turning of the World (pp. 274-275). Rochester: Destiny Books.

[2] Wikipedia. (2019, November 21). Cross-modal perception or cross-modal perception. Retrieved from https://gov.wales/ sites/default/files/publications/2019-05/natural-resourcespolicy-statement.pdf

[3] Gelfand, S. A. (2004). Hearing: An Introduction to Psychological and Physiological Acoustics. New York: Marcel Dekke.

[4] Van Kamp, I., Klæboe, R., Brown, A. L., \& Lercher, P. (2016). Soundscapes, Human Restoration, and Quality of Life. In J. Kang \& B. Schulte-Fortkamp (Eds.), Soundscape and the Built Environment. Boca Raton: CRC Press.

[5] Kang, J., Aletta, F., Gjestland, T. T., Brown, L. A., Botteldooren D., Schulte-Fortkamp, B., ... Lavia, L. (2016). Ten question on the soundscapes of the built environment. Building an Environment, (108), 284-294.

[6] Lavia, L., Dixon, M., Witchel, H. J., \& Goldsmith, M. (2016). Applied soundscape practices. In J. Kang \& B. SchulteFortkamp (Eds.), Soundscape and the Built Environment. Boca Raton: CRC Press.

[7] Halfwerk, W. \& Slabbekoorn, H. (2009). A behavioural mechanism explaining noise-dependent frequency use in urban birdsong. Animal Behaviour, 78(6), 1301-1307.

[8] Cardoso, G. C., \& Atwell, J. W. (2011). On the relation between loudness and the increased song frequency of urban birds. Animal Behaviour, 82(4), 831-836.

[9] International Organization for Standardization. (2014). ISO 12913-1:2014 Acoustics - Soundscape - Part 1: Definition and conceptual framework. Retrieved from https://www. iso. and conceptual framewo
org $/$ standard/52161.html

[10] Waddington, D., Kendrick, P., Kerry, G., Muirhead, M., \& Browne, R. (2008). Research into the Improvement of the Management of Helicopter in the UK. The Journal of the Acoustical Society of America, 123(5), 1453-1458. doi:10.1121/1.2933117

[11] Titley, K. C. S. (2009). Psychological Response to Helicopter Noise at RAF Shawbury. The 8th European Conference on Noise Control 2009, Euronoise 2009 - Proceedings of the Institute of Acoustics, (31).

[12] Zwicher, E., \& Fastl, H. (1999). Psychoacoustic: Facts and Models. New York: Springer.

[13] Hao, Y., Kang, J., \& Wörtche, H. (2016). Assessment of the masking effects of birdsong on the road traffic noise environment. Journal of the Acoustical Society of America, 140(2). 978-987. https://doi.org/10.1121/1.4960570

[14] Hellström, B. (2012). Acoustic design artifacts and methods for urban soundscapes: A case study on the qualitative dimensions of sounds. Inter-Noise and Noise-Con Congre and Conference Proceedings, Internoise 2012, New York.

[15] Boubezari, M., Bento Coelho, J. L., Mesquita, T., \& Alarcão, D. (2009). The soundscape project as an alternative solution for urban noisy places: The case of Alcântara Bridge in Lisbon. The European Conference on Noise Control, Edinburgh, UK.

6] Bento Coelho, J. L. (2016). Approaches to urban soundscape management, planning and design. In J. Kang \& B. SchulteFortkamp (Eds.), Soundscape and the Built Environment. Boca Raton: CRC Press.

[17] Mazaris, A. D., Kallimanis, A. S., Chatzigianidis, G., Papadimitriou, K., \& Pantis, J. D. (2009). Spatiotemporal analysis of an acoustic environment: Interactions between landscape features and sounds. Landscape Ecology, 24(6), 817-831. doi:10.1007/s10980-009-9360-x

[18] Yu, L., \& Kang, J. (2010). Factors influencing the sound preference in urban open spaces. Applied Acoustics, 71(7), 622-633.

[19] Kang, J. (2006). Urban Sound Environment. Boca Raton: CRC Press.

[20] Liu, J., Kang, J., Luo, T., \& Behm, H. (2013). Landscape effects on soundscape experience in city parks. Science of the Total Environment, (454-455), 474-481. https://doi.org/10.1016/ j.scitotenv.2013.03.038

[21] Hong, J. Y., \& Jeon, J. Y. (2013). Designing sound and visual components for enhancement of urban soundscapes. The Journal of the Acoustical Society of America, 134(3), 2026 2036.

[22] Hao, Y., Kang, J., \& Wörtche, H. (2016). Assessment of the masking effects of birdsong on the road traffic nois environment. The Journal of the Acoustical Society of America, 140(2), 978-987.

[23] Natural Resources Wales. (2015). Natural Resources Policy Statement. Retrieved from https://gov.wales/sites/default/ files/publications/2019-05/natural-resources-policystatement.pdf

[24] Natural Resources Wales. (2016). State of Natura Resources Report (SoNaRR): Assessment of the Sustainable
Management of Natural resources. Annex. Acronyms and Glossary of Terms. Retrieved from http://naturalresources. wales/media/679406/annex-acronyms-abbreviationsglossary-final-for-publication.pdf

[25] Department for Environment, Food and Rural Affairs. 12010 Noise Policy Statement for England (NPSE). Retrieved from https://assets.publishing.service.gov.uk/government/ uploads/system/uploads/attachment_data/file/69533/ pb13750-noise-policy.pdf

[26] Ministry of Housing, Communities and Local Government. (2014). Planning Practice Guidance. Retrieved from https:// www.gov.uk/government/collections/planning-practiceguidance

[27] Southworth, M. (1969). The sonic environment of cities. Environment and Behavior, 1(1), 49-70. https://do org/10.1177/001391656900100104

[28] Pheasant, R., Horoshenkov, K., Watts, G., \& Barrett, B. (2008]. The acoustic and visual factors influencing the construction of tranquil space in urban and rural environments tranquil spaces-quiet places?. The Journal of the Acoustical Society of America, 123(3), 1446-1457.

[29] Hao, Y., \& Kang, J. (2014). Influence of mesoscale urban morphology on the spatial noise attenuation of flyover aircrafts. Applied Acoustics, (84), 73-82. https://do org/10.1016/j.apacoust.2013.12.001

[30] Hao, Y., Kang, J., \& Krijnders, J. D. (2015). Integrated effects of urban morphology on birdsong loudness and visibility of green areas. Landscape and Urban Planning. (137), 149-162. https://doi.org/10.1016/j.landurbplan.2015.01.006

[31] De Coensel, B., Vanwetswinkel, S., \& Botteldooren, D. (2011). Effects of natural sounds on the perception of road traffic noise. The Journal of the Acoustical Society of America, 129(4), EL148-153. https://doi.org/10.1121/1.3567073

[32] Jeon, J. Y., Lee, P. J., You, J., \& Kang, J. (2010). Perceptual assessment of quality of urban soundscapes with combined noise sources and water sounds. The Journal of the Acoustical Society of America, 127(3), 1357-1366.

[33] Kang, J., Chourmouziadou, K., Sakantamis K., Wang, B., \& Hao, Y. (Eds.). (2013). COST TUD Action TD0804: Soundscape of European Cities and Landscapes. Retrieved from http://soundscape-cost.org/documents/COST_TD0804_ E-book_2013.pdf 